\title{
Decision Supporting System For Assessment Of Recruitment And Employees Management With Analytical Hierarchy Process (AHP) Method In PT. Indo Porcelain
}

Tri Hartati ${ }^{1}$, Rino $^{2}$

${ }^{1}$ Universitas Buddhi Dharma, Sistem Informasi, Banten, Indonesia

${ }^{2}$ Universitas Buddhi Dharma, Teknik Informatika, Banten, Indonesia

\begin{tabular}{|c|c|}
\hline SUBMISSION TRACK & 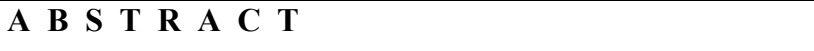 \\
\hline $\begin{array}{l}\text { Received } 20 \text { May } 2018 ; \\
\text { Revised } 5 \text { July } 2018 ; \\
\text { Accepted } 15 \text { September } 2018 ; \\
\text { Available online 20September } 2018\end{array}$ & $\begin{array}{l}\text { Managing human resources in the company is very important } \\
\text { where human resources are needed for the progress of the } \\
\text { company, in most companies, of course, can utilize all the } \\
\text { human resources obtained in accordance with the need to } \\
\text { contribute in accordance with the needs of the company to } \\
\text { achieve its goals. }\end{array}$ \\
\hline $\begin{array}{l}\text { Analysis, Design, Decision Support, } \\
\text { Recruitment, AHP (Analytical Hierarchy } \\
\text { Process) }\end{array}$ & $\begin{array}{l}\text { PT. Indo Porcelain is engaged in manufacturing with ceramic } \\
\text { dining table products, such as glassware, bowls and dishes. } \\
\text { Problems faced by PT. Indo Porcelain is the absence of an } \\
\text { integrated information system, so that the employee } \\
\text { recruitment process requires time in making selection }\end{array}$ \\
\hline E-mail: trie.hartatii@gmail.com & $\begin{array}{l}\text { decisions for prospective employees while at the same time } \\
\text { hampering the company's internal control. } \\
\text { With the decision support system using the Analytical } \\
\text { Hierarchy Process method, the recruitment process is faster } \\
\text { and easier. Information on the results of recruitment obtained } \\
\text { by company management becomes more structured so that } \\
\text { the decision support process taken by the management can } \\
\text { produce more accurate decisions.. }\end{array}$ \\
\hline
\end{tabular}

\section{INTRODUCTION}

The larger a company is, the greater the number of workers needed to contribute in accordance with the company's requirements to achieve approval. If labor issues are not systematically thought out, then of course they will adversely affect the company itself. This is intended so that the objectives of this company are agreed and implemented well. Recruitment and management system is one of the things related to the availability of integrated information in an effort to create a system with efficient and competitive prospective employee data management. Efficient and competitive management of prospective employee data will certainly affect the results of decision making by the company. A reliable system will also prevent the occurrence of weaknesses due to various forms of fraud, human error such as lost 
data, corrupted documents, important confidential data that is known to others, and also requires a process

further to make a recapitulation of prospective employee reports. Therefore, it is very important for companies to have a well integrated system in storing prospective employee data and at the same time supporting the company's internal control. AHP, developed by Thomas L. Saaty [1], can solve a fairly complex problem in which there are quite a number of aspects or criteria. This complexity can also be caused by the structure of the problem that is not yet clear, the uncertainty of perception in decision making and the unavailability of accurate statistical data or even virtually nonexistent. Sometimes a problem arises and must make a decision as soon as possible to solve the problem, but the variations are classified as complicated so that the data of the problem may not be numerically recorded.

\section{METHODS}

\section{Analytic Hierarchy Process Method (AHP)}

This method is a framework for making effective decisions on complex problems by simplifying and speeding up the decision making process by solving the problem into its parts, arranging these parts or variables in a hierarchical arrangement, giving numerical values to subjective considerations of the importance of each variable and synthesize these considerations to determine which variable has the highest priority and act to influence the outcome of the situation.

This AHP method helps solve complex problems by structuring a hierarchy of criteria, interested parties, outcomes and by attracting various considerations to develop weights or priorities. This method also combines the power of feelings and logic involved in various problems, then synthesizes various considerations into results that match our estimates intuitively as presented in the considerations that have been made [1].
The hierarchy process is a model that provides opportunities for individuals or groups to develop ideas anddefining the problem by making their respective assumptions and obtaining the desired solution from it. There are two reasonsThe main thing is to state an action is better than an action other. The first reason is the effects of these actions sometimes it cannot be compared because of the size or areadifferent and second, states that the effect of these actions sometimes clashing with each other, meaning the improvement of the effect of the actionone can be achieved by the other deterioration. Both of these reasonswill make it difficult to make equivalence between influences so thata flexible scale called priority is needed.

Strengths of AHP Unity (Unity), AHP can make abroad and unstructured problems into a model flexible and relatively easy to understand. Complexity (Complexity), AHP can solve a problem that is classified as complex through a systems approach and integrated deductive. Each otherdependency (Inter Dependence), AHP can be implemented on system elements that are not interconnected and do not require linear relationship. Hierarchy Structuring, AHP can represent natural thinking which tends to group elements the system into different levels where each level contains similar elements. Measurement (Measurement), AHP provides a measurement scale and method for obtaining values priority of each element of the criteria. Consistency, AHP consider a logical consistency value in the valuation used to determine a priority. Synthesis (Synthesis), AHP leads to an overall estimate in the hierarchy to find out how desirable each alternative is. Trade Off, AHP consider the relative priority of each factor contained in system so that people are able to choose the best alternative based on the goalas expected. Judgment and Consensus (Judgment and Consensus), AHP does not require a consensus, butcombining the results of a different assessment. RepetitionProcess (Process Repetition), AHP 
is able to make people filter definitionsfrom an issue and develops judgment and understandingthey go through a repetition process.

Disadvantages of AHP, AHP method has a dependency on inputthe main. The main input referred to is in the form of perception orinterpretation of an expert so that in this case involves the subjectivity of theexpert besides that the model becomes meaningless if the expert gives

wrong judgment. The AHP method is only a mathematical method. Without statistically testing based on historical data on problems that have been happened before, so there are no limits on trust and informationstrong supporter of the truth of the formed model. Analytic Hierarchy Process (AHP) method is onemethods in decision support systems that are unique incompare the others. This is because in weighting criteria, the weight of each criterion is not determined at the beginning but is determineduse the formula of this method based on priority scale (level interests) sourced from the current table. This method is a method which is perceptional, meaning the level of importance of a criterion alternatives depend on one's perspective or perspectiverate it.

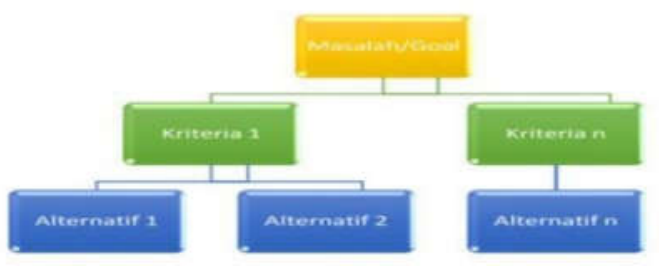

Figure 1. AHP Method Structure

The following is a table of importance used: Table 1. Value of Importance in the AHP Method [1]

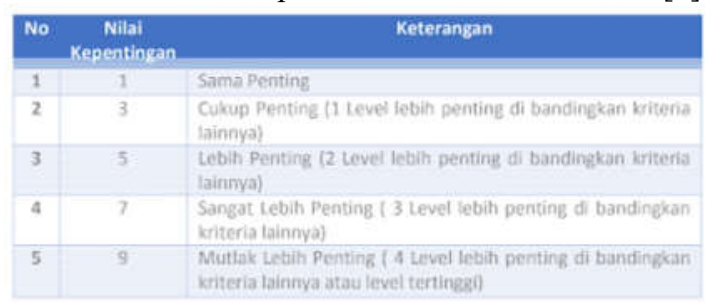

In this method there is a Consistency Index value. The table of Consistency Ratio values from the Analytic Hierarchy Process Method (AHP) method is as follows:

Table 2. Value of Consistency Index in AHP Method

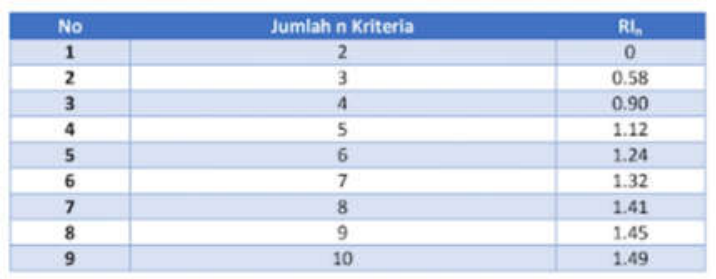

Named the Analytic Hierarchy Process Method (AHP) method because in this method the solution process is to solve each case by first completing the criteria weight matrix, then the alternatives. The uniqueness of this method compared to other methods, namely this method in determining the criteria weight $(\mathrm{Wj})$ based on the evaluation of the criteria weight matrix is not determined in advance by stakeholders compared to other methods. There are 3 (three) elements in the AHP method, namely:

1) Problems

2) Criteria

3) Alternative

The following is the structure of the Analytic Hierarchy Process Method (AHP) method, which is as follows:

The algorithm for solving the Analytic Hierarchy Process Method (AHP) method is as follows:

1) Step 1: Define in advance the criteria that will serve as benchmarks for solving problems and determine the level of importance of each criterion.

2) Step 2: Calculate the Comparison Matrix Value of each criterion based on the importance value table

3) Step 3: Calculate the criteria weight value $(\mathrm{Wj})$

4) Step 4: Calculate the Consistency Index value

5) Step 5: Calculate the value of Consistency Ratio

\section{RESULT}

Results The purpose of this study was to develop an already established modelformed 
by the AHP method. Data were analyzed by conducting a validity test and reliability, determine hypotheses, and calculations with the AHP method.

AHP (Analytical Hierarchy Process) is one of the methods in the system Supports decisions that are unique compared to others. This matter Because in the criteria, the weight of each criterion is not determinedStart by using the formula from this method based on priority scale(level of importance) sourced from the current table. This method is a methodwhich are perceptional, meaning the level of importance of an alternative criterion depending on one's point of view or point of view [2] [3]. Example Problems:

The most important part of the analysis process is the following 3 (three) stages:

1. State the purpose of the analysis:

Assessment of prospective employees

2. Determine the criteria: Psychotest,

Logic, Competence.

3. Determine alternative choices: Employee

1, Employee 2, Employee 3.

Table 3. Alternative Score

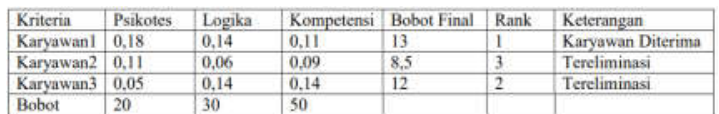

This information is then arranged to form a multilevel tree

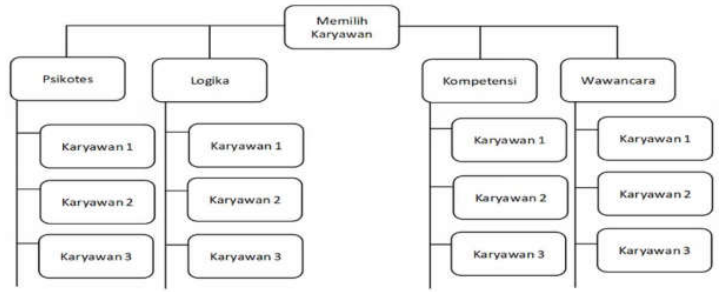

Figure 2. Tiered Tree Assessment Selecting Employees

Importance:

1 Fairly Important

3 Very important

5 Absolute Important

The following are the Calculation Results for the Candidates for Employee Candidates that are already in propose: Determination of Criteria

\begin{tabular}{lccc}
\hline \multicolumn{1}{l}{0,20} & 0,21 & $-0,01$ & 3 \\
0,30 & 0,30 & 0,00 & 2 \\
0,50 & 0,49 & 0,01 & 1 \\
Psikotes & 0,20 & 0,2000 Prioritas Ketiga \\
Logika & 0,30 & 0,3000 Prioritas Kedua \\
Kompetensi & 0,50 & 0,5000 Prioritas Pertama \\
& 1,00 & 1,0000
\end{tabular}

Segi Psikotes
\begin{tabular}{|l|l|l|l|}
\hline Karyawan1 & 10 & 0,53 & 0,18 \\
\hline Karyawan2 & 6 & 0,32 & 0,11 \\
\hline Karyawan3 & 3 & 0,16 & 0,05 \\
\hline TOTAL & 19 & & \\
\hline
\end{tabular}

Segi Logika

\begin{tabular}{|l|l|l|l|}
\hline Karyawan1 & 15 & 0,41 & 0,14 \\
\hline Karyawan2 & 7 & 0,19 & 0,06 \\
\hline Karyawan3 & 15 & 0,41 & 0,14 \\
\hline TOTAL & 37 & & \\
\hline
\end{tabular}

Segi Kompetensi

\begin{tabular}{|l|l|l|l|}
\hline Karyawan1 & 7 & 0,32 & 0,11 \\
\hline Karyawan2 & 6 & 0,27 & 0,09 \\
\hline Karyawan3 & 9 & 0,41 & 0,14 \\
\hline TOTAL & 22 & & \\
\hline
\end{tabular}

2

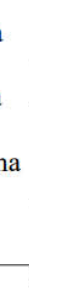




\section{DISCUSSION}

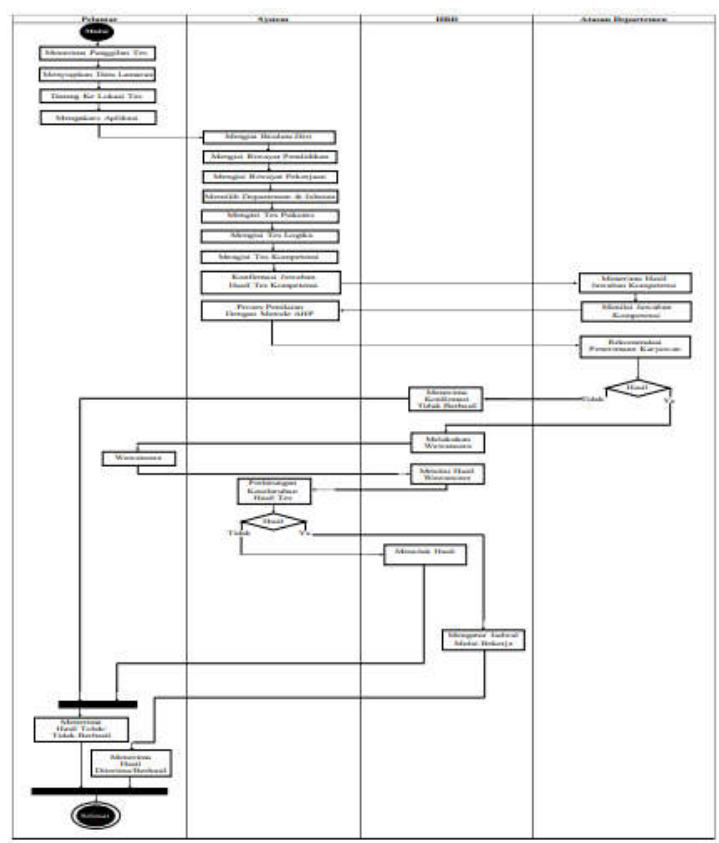

Figure 3. Activity Diagram of Employee Recruitment Assessment Application

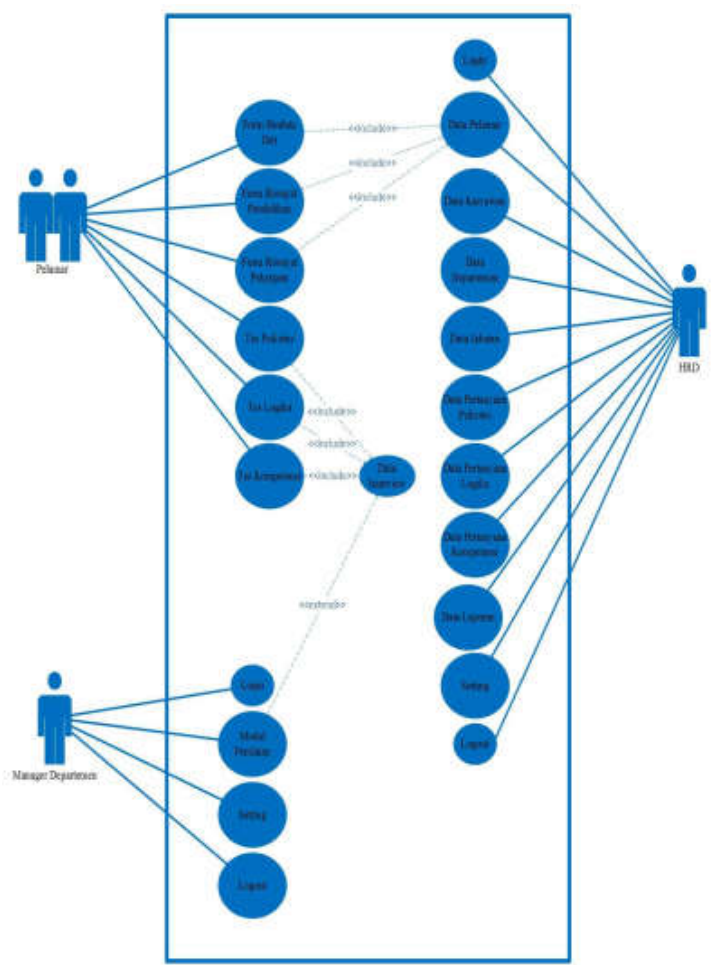

Figure 4. Use Case Diagram of Employee Recruitment Assessment Applications

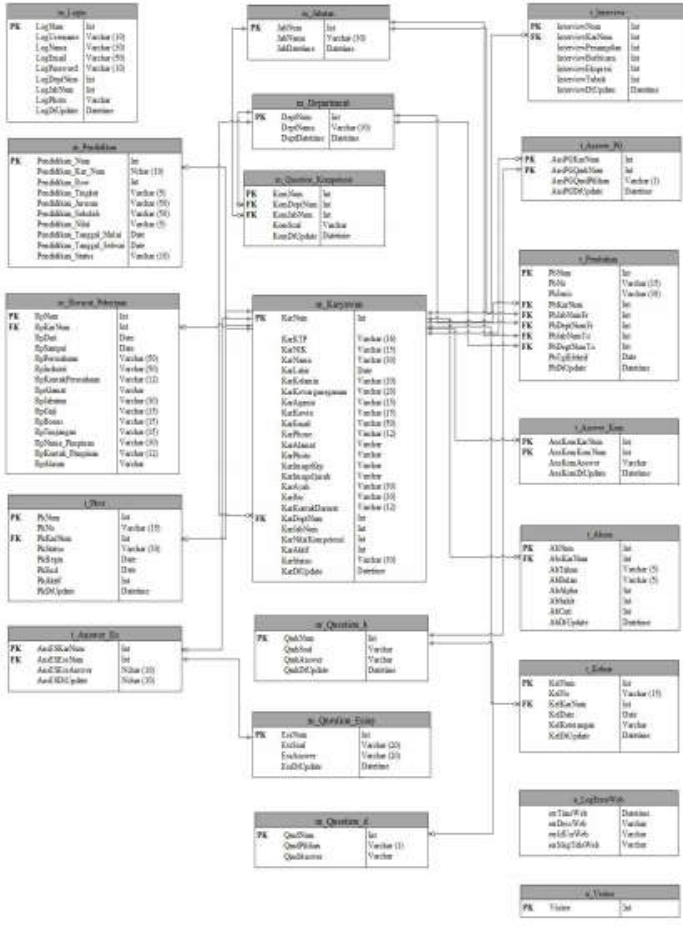

Figure 5. Entity Relationship Diagram

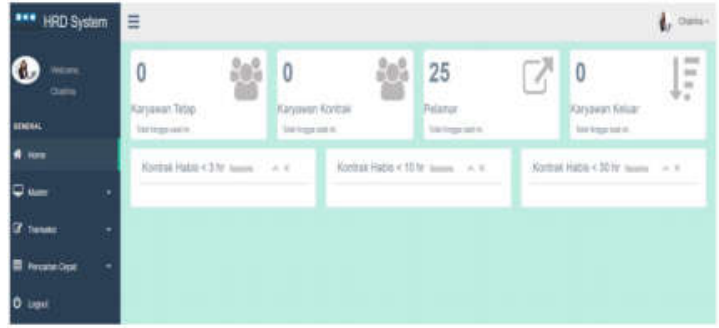

Figure 6. Display Home Page HRD Application

\section{CONCLUSION}

By developing information systems it can improve the quality of work, so that the information system provided can provide benefits and help the company in supporting the decision.

Based on the results of research and making applications at PT. Indo Porcelain, then some - some conclusions, namely:

1. With this application it is very helpful for employees in terms ofdo individual tests and speed tests or ability tests because you can measured based on certain characteristics.

2. With this application, it is very helpful for department managers 
conduct an assessment of The variables taken into account in the competency tests in the field of work. employee appraisal application are:

3. With this application it is very helpful for the HRD to do calculation of valuation as a consideration for supporting decisions and not need to check the completeness of employee data, as it is this application employee data has been configured in the application.

4. By using the AHP method this application can work with the maximum and get accurate results.

1. Evaluation of the results of the psychological test which is to get a weight of 20 (Important enough)

2. Evaluate the results of the logic test which is to get a weight of 30 (Very Important)

3. Evaluation of the results of the competency ability test that is weighted 50 (Absolute Important)

\section{REFERENCES}

[1] T.L, Saaty, "The Analytic Hierarchy Process". McGraw-Hill, New York, 1980

[2] D, Nofriansyah, S. Deficits "Multi Criteria Decision Making (MCDM) pada Sistem Pendukung Keputusan”. Deepublish, Yogyakarta. 2017

[3] D, Nofriansyah, “Konsep Data Mining Vs Sistem Pendukung Keputusan”. Deepublish, Yogyakarta. 2014

\section{BIOGRAPHY}

Tri Hartati received his Bachelor degree in Information System (S.Kom) from Buddhi Dharma University, Indonesia. Currently working as finance acounting at PT Indo Porcelain.

Rino received his Bachelor degree in Information Technology(S.Kom) from Buddhi Dharma University, Indonesia and Master Degree in Computer Sciences (M.Kom) concentration in Software Engineering from Eresha University, Indonesia. $\mathrm{He}$ is a lecturer at the Department of Information System, Faculty of Information Technology, Buddhi Dharma University. 
TRI HARTATI / JURNAL TECH-E - VOL. 2. NO. 1 (2018) 